\title{
Synthesis and Characterization of 3s,5s,7s-Adamantan-1-Amine Complexes with Metals of Biological Interest
}

\section{Najma Sultana ${ }^{1}$, Saeed Arayne $\mathbf{M}^{2 *}$, Amir Haider ${ }^{2}$ and Hina Shahnaz ${ }^{3}$}

${ }^{1}$ Research Institute of Pharmaceutical Sciences, Faculty of Pharmacy, University of Karachi, Karachi, Pakistan

${ }^{2}$ Department of Chemistry, University of Karachi, Karachi, Pakistan

${ }^{3}$ Department of Environmental Science, Sind Madressatul Islam University, Karachi, Pakistan

\begin{abstract}
3s,5s,7s-adamantan-1-amine, tricyclo[3.3.1.13,7]decan-1-amine, 1-adamantanamine, 1-aminoadamantane, 1-aminotricyclo[3.3.1.13,7]decane, 1-adamantylamine or amantadine with a tricyclic amine with cage like structure is an antiviral and antiparkinsonian compound. It also is used to prevent and treat respiratory infections caused by influenza A virus. Eleven metal complexes of amantadine with metals of biological interest as Mg", Call, $\mathrm{Cr}^{\prime \prime}, \mathrm{Mn}^{\prime \prime}, \mathrm{Fe}^{\prime \prime}$, $\mathrm{Fe}^{\prime \prime \prime}, \mathrm{Co}$ 'I, Ni", Cu", Zn" and Cd"I have been synthesized and characterized by spectroscopic techniques IR, 1H NMR, elemental analysis and atomic absorption spectroscopy. Prior to synthesis condutometric titrations were carried out to determine the mole ratios of drug metal interactions. In all complexes, amantadine acted as a monodentate ligand, two molecules of which are bound to the metal through the amino nitrogen showing a square planar geometry.
\end{abstract}

Keywords: Amantadine; Metal complexes; Conductance; FT-IR; ${ }^{1} \mathrm{H}-\mathrm{NMR}$

\section{Introduction}

Tricyclic amines have a great potential in the treatment and prevention of influenza A of which the most significant is amantadine, a synthetic alicyclic antiviral agent with an unusual cage like structure (Figure 1) [1]. Amantadine is an orally active antiparkinsonian and antiviral agent $[2,3]$ discovered by workers at DuPont via an empiric screening program [1].

Amantadine hydrochloride possesses a unique, rigid, relatively unstrained ring system that is composed of three fused cyclohexane rings in the chair conformation [4]. Amantadine is considered to be the smallest repeating unit of the diamond lattice [5]. The symmetrical cage structure causes the infrared, nuclear magnetic resonance and mass spectra to be comparatively simple, as will be illustrated later.

Several metal complexes of amantadine are reported with iron [6], platinum [7], while other polyoxometalates containing $\mathrm{Ce}, \mathrm{W}, \mathrm{Pr}, \mathrm{Ni}, \mathrm{V}$ and $\mathrm{Mn}$ were reported by Liu and others [8]. Compounds of molybdenum and amantadine with the formulae, $\left(\mathrm{C}_{10} \mathrm{H}_{18} \mathrm{~N}\right)_{5} \mathrm{PMo}_{12} \mathrm{O}_{40} \mathrm{Cl}_{2} .5 \mathrm{H}_{2} \mathrm{O},\left(\mathrm{C}_{10}\right.$ $\left.\mathrm{H}_{18} \mathrm{~N}\right)_{6} \mathrm{As}_{2} \mathrm{Mo}_{18} \mathrm{O}_{62} \cdot 6 \mathrm{CH}_{3} \mathrm{CN} .6 \mathrm{H}_{2} \mathrm{O}$ [9], $\left(\mathrm{C}_{10} \mathrm{H}_{18} \mathrm{~N}\right)_{4} \mathrm{Mo}_{8} \mathrm{O}_{26.6}\left(\mathrm{CH}_{3}\right)_{2} \mathrm{SO}$ [10] and trans- $(\mathrm{AdNH})_{2} \mathrm{Mo}\left(\mathrm{OSiMe}_{3}\right)_{4}[11]$ have also been reported. At physiological $\mathrm{pH}$ amatadine forms complex with sodium molybdate, as the amino group of the drug is free for its function as antiviral, this study

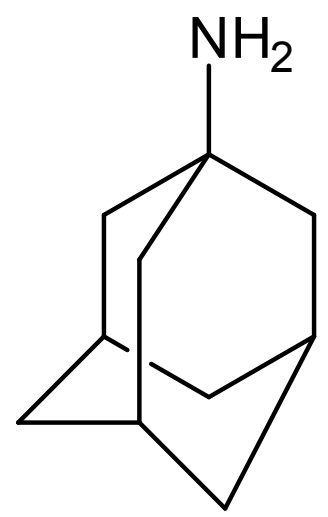

Figure 1: Amantadine suggests that the co-administration of amantadine with molybdenum supplements should be avoided [8].

Physical properties as solubility in water, size and ionic nature which in turn are dependent on the $\mathrm{pH}$ of the medium [12-14] effect the absorption of a drug through gastrointestinal tract. As only the free and unchanged drug can function at the active site in the body, if molybdate reacts with amantadine or when the two are administered together, the solubility and absorption can be affected. Owing to the fact that molybdnium is neither present in the body nor is administered as drug. Alternatively, essential and trace elements can be studied for complexation with amantadine, as being the metals of biological interest. In this paper we report synthesis and characterization of eleven metal complexes of amantadine with $\mathrm{Mg}^{\mathrm{II}}, \mathrm{Ca}^{\mathrm{II}}, \mathrm{Cr}^{\mathrm{II}}, \mathrm{Mn}^{\mathrm{II}}, \mathrm{Fe}^{\mathrm{II}}, \mathrm{Fe}^{\mathrm{III}}$, $\mathrm{Co}^{\mathrm{II}}, \mathrm{Ni}^{\mathrm{II}}, \mathrm{Cu}^{\mathrm{II}}, \mathrm{Zn}^{\mathrm{II}}$ and $\mathrm{Cd}^{\mathrm{II}}$, which were characterized by FT-IR, ${ }^{1} \mathrm{H}$ NMR, atomic absorption spectroscopy and elemental analysis.

\section{Materials and Methods}

\section{Chemicals}

Amantadine was purchased from Sigma-Aldrich USA. The essential and trace elements used were in the form of their hydrated chloride salts of magnesium, calcium, chromium, manganese, ferric, cobalt, nickel, copper, zinc and cadmium, all of analytical grade. Methanol (TEDIA', USA), hydrochloric acid, sodium hydroxide from Merck, Darmstadt, Germany. Deionized water was freshly prepared in the laboratory and all glasswares were washed with chromic acid and then thoroughly rinsed with deionized water.

\section{Instruments}

Electrical balance [Mettler Toledo AB54], pH meter [Mettler Toledo

*Corresponding author: Saeed Arayne M, Department of Chemistry, University of Karachi, Karachi-75270, Pakistan, Tel: +92-213-466-4402-03; E-mail: msarayne@gmail.com

Received November 22, 2013; Accepted February 26, 2014; Published March 03, 2014

Citation: Sultana N, Arayne MS, Haider A, Shahnaz H (2014) Synthesis and Characterization of 3s,5s,7s-Adamantan-1-Amine Complexes with Metals of Biological Interest. Mod Chem appl 2: 120. doi:10.4172/2329-6798.1000120

Copyright: $\odot 2014$ Sultana N, et al. This is an open-access article distributed under the terms of the Creative Commons Attribution License, which permits unrestricted use, distribution, and reproduction in any medium, provided the original author and source are credited. 
MP220], UV-Visible double beam spectrophotometer (Shimadzu $1601), 1 \mathrm{~cm}$ rectangular quartz cells, ground glass distillation assembly, (Quickfit), de-ionizer (Stedec CSW -300), water distillation unit (GFL type 2001/2, No. 10793600G), melting point apparatus (Gallenkamp), FT-IR spectrophotometer (Nicolet Avatar 330) and proton NMR (Bruker); CHN elemental analysis were carried on Carlo Erba 1106, HSF-254. The reactions were monitored on TLC plates coated with Silica gel HF-254 and compounds were observed under UV lamp (254 $\mathrm{nm}$ ). Perkin-Elmer AAnalyst 700 atomic absorption spectrometer used for atomic absorption studies.

\section{Conductometric titration of amantadine metal complexes}

Prior to synthesis conductometric titrations were performed to study the stoichiometric ratio of amantadine metal interactions in aqueous medium using conductivity/TDS meter. In individual experiments metal solutions of $1 \mathrm{mM}$ were prepared and titrated with $1 \mathrm{mM}$ ligand solution at $25^{\circ} \mathrm{C}$. Conductivity of reacting mixtures were recorded after each addition of metal solution aliquots.

\section{Synthesis of amantadine metal complexes}

Amantadine $(2 \mathrm{mM})$ was dissolved in $0.1 \mathrm{~N} \mathrm{HCl}$ and $1 \mathrm{mM}$ of each of these element salts were individually dissolved in $10 \mathrm{~mL}$ of methanol. Both of these solutions were mixed together and refluxed for three hours; the solution was concentrated and filtered while hot and then kept undisturbed for crystal growth at room temperature. The growth of crystals had a different time of crystallization. Crystals of magnesium, calcium, and chromium and manganese complexes with amantadine appeared in 15 days while the iron complex took one month for crystallization. On the other hand, cobalt, nickel, copper, zinc and cadmium complexes took 25 30 days for their growth. These

\begin{tabular}{|c|c|c|c|c|c|c|}
\hline Metal & $\begin{array}{c}\text { Concentration } \\
\text { of standard } \\
\text { (ppm) }\end{array}$ & $\begin{array}{c}\text { Absorbance } \\
\text { of standard }\end{array}$ & $\begin{array}{c}\text { Absorbance } \\
\text { of sample }\end{array}$ & $\begin{array}{c}\text { Concentration } \\
\text { of sample/50 } \\
\mathbf{m L}\end{array}$ & $\%$ & S.D \\
\hline $\mathrm{Mg}$ & 0.3 & 0.198 & 0.37 & 23800 & 23.8 & 0.000 \\
\hline $\mathrm{Ca}$ & 4 & 0.191 & 5.3 & 30430 & 30.43 & 0.021 \\
\hline $\mathrm{Cr}$ & 4 & 0.192 & 0.78 & 38780 & 38.78 & 0.012 \\
\hline $\mathrm{Mn}$ & 2.5 & 0.19 & 1.86 & 39890 & 39.89 & 0.013 \\
\hline $\mathrm{Fe}$ & 5 & 0.198 & 1.54 & 40100 & 40.10 & 0.025 \\
\hline $\mathrm{Co}$ & 7 & 0.199 & 0.34 & 42340 & 42.34 & 0.020 \\
\hline $\mathrm{Ni}$ & 7 & 0.198 & 5.35 & 42220 & 42.22 & 0.020 \\
\hline $\mathrm{Cu}$ & 4 & 0.197 & 0.23 & 46120 & 46.12 & 0.012 \\
\hline $\mathrm{Zn}$ & 1 & 0.204 & 1.81 & 44790 & 44.79 & 0.005 \\
\hline $\mathrm{Cd}$ & 1.5 & 0.196 & 1.22 & 58230 & 58.23 & 0.004 \\
\hline
\end{tabular}

Table 1: Atomic absorption analysis of amantadine metal complexes.

\begin{tabular}{|c|c|c|c|c|}
\hline Sample & Melting point ${ }^{\circ} \mathbf{C}$ & Mole ratio & $\begin{array}{c}\text { Solubility } \\
\mathbf{H}_{\mathbf{2}} \mathbf{O}: \mathbf{H C l}\end{array}$ & Color \\
\hline Amantadine & 180 & & $1: 1$ & White \\
\hline Amn+Mg & 210 & $1: 2$ & $1: 2$ & White \\
\hline $\mathrm{Amn}+\mathrm{Ca}$ & 192 & $1: 2$ & $1: 2$ & White \\
\hline $\mathrm{Amn}+\mathrm{Cr}$ & 200 & $1: 2$ & $1: 2$ & Green \\
\hline $\mathrm{Amn}+\mathrm{Mn}$ & 228 & $1: 2$ & $1: 2$ & White \\
\hline $\mathrm{Amn}+\mathrm{FeCl}$ & 112 & $1: 2$ & $1: 2$ & Yellow \\
\hline $\mathrm{Amn}+\mathrm{FeSO}$ & 210 & $1: 2$ & $1: 2$ & Light yellow \\
\hline $\mathrm{Amn}+\mathrm{Co}$ & 218 & $1: 2$ & $1: 2$ & Blue \\
\hline $\mathrm{Amn}+\mathrm{Ni}$ & 212 & $1: 2$ & $1: 2$ & Light green \\
\hline $\mathrm{Amn}+\mathrm{Cu}$ & 210 & $1: 1$ & $1: 2$ & Blue \\
\hline $\mathrm{Amnn}+\mathrm{Zn}$ & 202 & $1: 1$ & $1: 2$ & Off white \\
\hline $\mathrm{Amn}+\mathrm{Cd}$ & 232 & $1: 1$ & $1: 2$ & White \\
\hline
\end{tabular}

Table 2: Physicochemical parameters of amantadine and its metal complexes. metal complexes were recrystallized in absolute methanol, filtered, dried and physical characteristics were recorded.

\section{Results and Discussion}

\section{Synthesis of complexes}

A venture has been made to synthesize metal complexes of amantadine with various essential and trace elements in equimolar ratio in a mixture of hydrochloric acid and methanol. These complexes were than studied for their physicochemical parameters and characterized using techniques as IR, NMR and elemental analysis. Metals in all amantadine complexes were determined by using Pye-Unicam atomic absorption spectrometer (Table 1). Melting points were recorded on Gallenkamp melting point apparatus, while solubilities of all the complexes were checked and are present in Table 2.

\section{IR Studies}

All the synthesized complexes were studied spectroscopically in the IR region 4000 to 400 wavenumbers $\left(\mathrm{cm}^{-1}\right)$. The infrared spectrum of amantadine and their metal complexes were recorded as a potassium bromide disc method on a Nicolet Avatar 330 IR spectrophotometer. The main peak assignments are given in Table 3.

\section{N-H stretch}

The N-H stretching band of the amino group expected for amantadine is in the region 2961- 3087 [15,16] was observed for pure amantadine at $3038 \mathrm{~cm}^{-1}$ which shifts to $2900-3600 \mathrm{~cm}^{-1}$.

For magnesium complex, N-H stretch band appeared at $3400 \mathrm{~cm}^{-1}$ as small band where as for calcium complex, a broad band was observed in the range of $3600-3100 \mathrm{~cm}^{-1}$ due to $\mathrm{N}-\mathrm{H}$ stretching. In chromium and cadmium complexes, $\mathrm{N}-\mathrm{H}$ stretch showed a short band at 3400 $\mathrm{cm}^{-1}$, similarly in case of manganese, ferric chloride, cobalt, nickel, copper, zinc complexes a medium band was observed in the range of $3600-3100 \mathrm{~cm}^{-1}$ due to $\mathrm{N}-\mathrm{H}$ stretching. While in ferrous ammonium citrate complex, $\mathrm{N}-\mathrm{H}$ stretching showed a weak band in the region of $3400-3100 \mathrm{~cm}^{-1}$

The second incredibly significant peaks were asymmetric and symmetric stretching and their scissoring wagging and rocking which is the evidence of the attachment of metal with nitrogen of amine group. The $\mathrm{CH}_{2}$ symmetric stretching was recorded at $2860 \mathrm{~cm}^{-1}$, scissoring at $1449 \mathrm{~cm}^{-1}$, rocking at $1263 \mathrm{~cm}^{-1}$ and wagging was at $1143 \mathrm{~cm}^{-1}$. The comparison of the IR spectra of amantadine with metal complexes divulged that in case of all complexes the N-H stretching peak was shifted to $2914-3395 \mathrm{~cm}^{-1}$ in doublet and triplet weak bands.

\section{$\mathrm{CH}_{2}$ stretching (antisymmetric and symmetric)}

Amantadine showed a very sharp band at $2900 \mathrm{~cm}^{-1}$ due to $\mathrm{CH}_{2}$ antisymmetric and $2850 \mathrm{~cm}^{-1}$ due to $\mathrm{CH}_{2}$ symmetric stretching whereas the reported peaks for antisymmetric is $2923 \mathrm{~cm}^{-1}$ and symmetric stretching at $2900 \mathrm{~cm}^{-1}$ [5]. For magnesium and calcium complex antisymmetric peaks appeared at $2900 \mathrm{~cm}^{-1}, 2950 \mathrm{~cm}^{-1}$ and symmetric very short band and sharp bands were observed at 2850 $\mathrm{cm}^{-1}$ for magnesium and calcium complexes. This band disappeared in chromium complex, whereas manganese, ferric chloride and ferric ammonium citrate nickel complexes showed suppressed bands of $\mathrm{CH}_{2}$ stretching (antisymmetric and symmetric) at $2900 \mathrm{~cm}^{-1}$. In cobalt complex very sharp symmetric band of $\mathrm{CH}_{2}$ stretching was observed at $2850 \mathrm{~cm}^{-1}$ and in zinc and cadmium complexes very sharp asymmetric bands were observed at $2900 \mathrm{~cm}^{-1}$ and incredibly very short symmetric bands appeared between $2850-2860 \mathrm{~cm}^{-1}$. 
Citation: Sultana N, Arayne MS, Haider A, Shahnaz H (2014) Synthesis and Characterization of 3s,5s,7s-Adamantan-1-Amine Complexes with Metals of Biological Interest. Mod Chem appl 2: 120. doi:10.4172/2329-6798.1000120

Page 3 of 5

\begin{tabular}{|c|c|c|c|c|c|c|c|c|c|}
\hline Compounds & $\mathrm{v}(\mathrm{N}-\mathrm{H})$ stretching & $\begin{array}{c}\mathrm{U}(\mathrm{N}-\mathrm{H}) \\
\text { bending }\end{array}$ & $\begin{array}{l}\mathrm{v}(\mathrm{N}-\mathrm{H}) \text { oop } \\
\text { bending }\end{array}$ & $\begin{array}{c}\mathrm{v}(\mathrm{N}-\mathrm{H}) \\
\text { stretching }\end{array}$ & $\mathrm{v}_{\text {asym }}\left(\mathrm{CH}_{2}\right)$ stretch & $\mathrm{v}_{\text {sym }}\left(\mathrm{CH}_{2}\right)$ stretch & $\mathrm{v}\left(\mathrm{CH}_{2}\right)$ scissoring & $\mathrm{v}\left(\mathrm{CH}_{2}\right)$ rocking & $\begin{array}{c}\mathrm{v}\left(\mathrm{CH}_{2}\right) \\
\text { wagging }\end{array}$ \\
\hline Amantadine & 2894 & 1608 & 811 & 1364 & 2860 & - & 1449 & 1263 & 1143 \\
\hline $\mathrm{Amn}+\mathrm{Mg}$ & 2920 & 1515 & 914 & 1080 & 2854 & 2711 & 1496 & 1313 & 1200 \\
\hline $\mathrm{Amn}+\mathrm{Ca}$ & 3300,2914 & 1517 & 898 & 1090 & 2857 & 2708 & 1499 & 1366 & 1203 \\
\hline $\mathrm{Amn}+\mathrm{Cr}$ & 3123,2923 & 1585 & 815 & 1090 & 2844 & 2658 & 1487 & 1329 & 1197 \\
\hline $\mathrm{Amn}+\mathrm{Mn}$ & $3212,3073,3046$ & 1575 & 951 & 1092 & 2837 & - & 1479 & 1363 & 1203 \\
\hline $\mathrm{Amn}+\mathrm{FeCl}_{3}$ & $3173,3116,3050$ & 1595 & 961 & 1080 & 2850 & - & 1472 & 1366 & 1193 \\
\hline $\mathrm{Amn}+\mathrm{FeSO}_{4}$ & $3176,3119,2954$ & 1578 & 957 & 1077 & 2854 & - & 1476 & 1366 & 1197 \\
\hline $\mathrm{Amn}+\mathrm{CO}$ & 3365,2906 & 1570 & 912 & 1094 & 2867 & - & 1480 & 1324 & 1206 \\
\hline $\mathrm{Amn}+\mathrm{Ni}$ & $3179,2920-2904$ & 1589 & 963 & 1080 & 2854 & - & 1472 & 1378 & 1203 \\
\hline $\mathrm{Amn}+\mathrm{Cu}$ & $3212,3010-2910$ & 1569 & 918 & 1090 & 2904 & - & 1476 & 1373 & 1207 \\
\hline$A m n+Z n$ & 3084,2904 & 1574 & 964 & 1088 & 2850 & - & 1476 & 1311 & 1200 \\
\hline$A m n+C d$ & 2914 & 1588 & 974 & 1097 & 2860 & 2728 & 1456 & 1366 & 1200 \\
\hline
\end{tabular}

Table 3: Infrared assignments of amantadine metal complexes.

\begin{tabular}{|c|c|c|c|c|c|c|c|}
\hline Drug \& metal complex & $\left(\mathrm{CH}_{2}\right)^{2}$ & J Values (Hz) & $\left(\mathrm{CH}_{2}\right)_{3}$ & J Values (Hz) & $\left(\mathrm{CH}_{2}\right)_{10}$ & J Values (Hz) & NH \\
\hline Amantadine & $1.71,1.42$ & $2.13,11.48$ & $1.18,1.56$ & $2.79,4.21$ & $1.18,1.78$ & $7.85,6.78$ & $1.45,1.48$ \\
\hline Mg complex & $1.59,1.49$ & $2.52,11.57$ & $1.23,1.61$ & $2.90,4.35$ & $1.23,1.67$ & $7.90,6.30$ & - \\
\hline Ca complex & $1.68,1.38$ & $2.65,11.64$ & $1.20,1.67$ & $2.89,4.41$ & $1.45,1.61$ & $7.71,6.27$ & - \\
\hline Cr complex & $1.65,1.32$ & $2.58,11.76$ & $1.21,1.60$ & $2.91,4.56$ & $1.43,1.65$ & $7.69,6.22$ & - \\
\hline Mn complex & $1.64,1.45$ & $2.65,11.63$ & $1.01,1.63$ & $2.93,4.77$ & $1.32,1.90$ & $7.67,6.31$ & - \\
\hline $\mathrm{Fe}^{+3}$ complex & $1.68,1.49$ & $2.76,11.60$ & $1.29,1.61$ & $2.67,4.29$ & $1.29,1.96$ & $7.75,6.36$ & - \\
\hline $\mathrm{Fe}^{+2}$ complex & $1.68,1.37$ & $2.31,11.59$ & $1.27,1.70$ & $2.7,4.34$ & $1.31,1.82$ & $7.93,6.40$ & - \\
\hline Co complex & $1.62,1.35$ & $2.71,11.62$ & $1.21,1.61$ & $2.65,4.43$ & $1.38,1.94$ & $7.69,6.29$ & - \\
\hline Ni complex & $1.60,1.38$ & $2.77,11.48$ & $1.23,1.63$ & $2.64,4.67$ & $1.23,1.98$ & $7.90,6.30$ & - \\
\hline Cu complex & $1.78,1.49$ & $2.22,11.68$ & $1.09,1.65$ & $261,4.33$ & $1.29,1.90$ & $7.91,6.22$ & - \\
\hline Zn complex & $1.62,1.47$ & $2.38,11.71$ & $1.09,1.66$ & $2.87,4.38$ & $1.44,1.83$ & $7.67,6.24$ & - \\
\hline Cd complex & $1.55,1.44$ & $2.21,11.56$ & $1.22,1.61$ & $2.81,4.41$ & $1.27,1.89$ & $7.70,6.29$ & - \\
\hline
\end{tabular}

Table 4: Chemical shifts (ppm) in $1 \mathrm{H}$ NMR spectra of amantadine and its metal complexes.

\section{$\mathrm{N}-\mathrm{H}$ overtones, $\mathrm{N}-\mathrm{H}$ deformation and $\mathrm{CH}_{2}$ deformation}

Amantadine showed N-H overtones at $2000 \mathrm{~cm}^{-1}, \mathrm{~N}-\mathrm{H}$ deformation at $1608 \mathrm{~cm}^{-1}, 1535 \mathrm{~cm}^{-1}, 1364 \mathrm{~cm}^{-1}$ and $\mathrm{CH}_{2}$ deformation at $1449 \mathrm{~cm}^{-1}$ while reported for $\mathrm{N}-\mathrm{H}$ overtones at $2000 \mathrm{~cm}^{-1}, \mathrm{~N}-\mathrm{H}$ deformation at $1608 \mathrm{~cm}^{-1}, 1364 \mathrm{~cm}^{-1}$ and $\mathrm{CH}_{2}$ deformation at $1452 \mathrm{~cm}^{-1}$ [5] are observed. For magnesium complex, N-H deformation was observed at 1515 $\mathrm{cm}^{-1}, 1510 \mathrm{~cm}^{-1}, 1365 \mathrm{~cm}^{-1}$ as suppressed bands and $\mathrm{CH}_{2}$ deformation suppressed band at $1496 \mathrm{~cm}^{-1}$. N-H overtones observed at $2000 \mathrm{~cm}^{-1}$ for all amantadine complexes. For calcium complex, $\mathrm{N}-\mathrm{H}$ deformation shifted to $1517-20 \mathrm{~cm}^{-1}, 1499 \mathrm{~cm}^{-1}$ and $1366 \mathrm{~cm}^{-1}, \mathrm{~N}-\mathrm{H}$ overtones at $2000 \mathrm{~cm}^{-1}$ and $\mathrm{CH}_{2}$ deformation suppressed at $1452 \mathrm{~cm}^{-1}$ have been recorded. In all metal-amantadine complexes the $\mathrm{N}-\mathrm{H}$ bending and C-N stretching were at a lower wavelength at $1515-1589 \mathrm{~cm}^{-1}$ and $1097-$ $1077 \mathrm{~cm}^{-1}$, respectively.

\section{$\mathrm{CH}_{2}$ wag and fingerprint region}

Amantadine showed $\mathrm{CH}_{2}$ wag sharp band at $1320 \mathrm{~cm}^{-1}$ and fingerprint region at $1300 \mathrm{~cm}^{-1}$ and below while reported $\mathrm{CH}_{2}$ wag at $1307 \mathrm{~cm}^{-1}$ [5]. For magnesium complex, $\mathrm{CH}_{2}$ wag at $1320 \mathrm{~cm}^{-1}$ (suppressed and doublet band), for calcium and manganese, ferrous ammonium citrate, ferric chloride, nickel, copper, zinc and cadmium complexes complexes suppressed bands were observed $1307-1310 \mathrm{~cm}^{-1}$.

Due to the coordination of the metal ion with amantadine the $\mathrm{N}-\mathrm{H}$, $\mathrm{C}-\mathrm{N}$ bands shifted to higher frequencies and overlapped [15]. It may be inferred that metal ions were strongly coordinated with amantadine through direct association with primary amine group [16,17].

\section{${ }^{1}$ NMR studies}

By comparing main peaks of amantadine with its complexes (Table
4 ), it is observed that amine resonance was absent in the spectra of all metal complexes. The reported $\mathrm{NH}_{2}$ (for $\mathrm{C}-1$ ), $\beta-\mathrm{CH}_{2}$ (for $\mathrm{C}-2, \mathrm{C}-8$, $\mathrm{C}-9$ ), $\delta-\mathrm{CH}_{2}$ (for $\left.\mathrm{C}-4, \mathrm{C}-6, \mathrm{C}-10\right), \delta-\mathrm{CH}(\mathrm{C}-3, \mathrm{C}-5, \mathrm{C}-7)$ groups of actual drug, showed their presence at $\delta 1.35, \delta 1.55, \delta 1.62, \delta 2.05$ [5]. While the ${ }^{1} \mathrm{NMR}$ of the reference drug in $\mathrm{D}_{2} \mathrm{O}$ at $600 \mathrm{MHz}$ showed signal at $1.4(\mathrm{~d}, 2 \mathrm{H}, \mathrm{J}=12.27)$ assigned for $\mathrm{C}-1$ inferred the presence of $\mathrm{NH}_{2}$ group. A doublet at $\delta 1.5$ having coupling constant $\mathrm{J}=11.48$ confirmed the presence of $\beta-\mathrm{CH}_{2}$ groups for $\mathrm{C}-2, \mathrm{C}-8, \mathrm{C}-9$ positions. A doublet appeared at $\delta 1.78$ assigned for $\delta-\mathrm{CH}_{2}$ groups at $\mathrm{C}-4, \mathrm{C}-6$, $\mathrm{C}-10$ positions $(\mathrm{J}=7.85)$ and the presence of $\mathrm{CH}$ groups at $\mathrm{C}-3, \mathrm{C}-5$, C-7 showed singlet at s, $\mathrm{H} \delta 1.56$.

The magnesium complex, in $\mathrm{CD}_{3} \mathrm{OD}+\mathrm{CDCl}_{3}$ at $600 \mathrm{MHz}$, showed a doublet at $\delta 1.49$ having coupling constant $\mathrm{J}=2.52$ confirmed the presence of $\beta-\mathrm{CH}_{2}$ groups for $\mathrm{C}-2, \mathrm{C}-8, \mathrm{C}-9$ positions. A doublet appeared at $\delta 1.67(\mathrm{~J}=7.9)$ assigned for $\delta-\mathrm{CH}_{2}$ groups at $\mathrm{C}-4, \mathrm{C}-6$, $\mathrm{C}-10$ positions and the presence of $\gamma-\mathrm{CH}$ groups at $\mathrm{C}-3, \mathrm{C}-5, \mathrm{C}-7$ showed singlet at $\delta 1.61$. Calcium complex confirmed the complex formation, and a doublet at $\delta 1.68$ having coupling constant $\mathrm{J}=11.64$ confirmed the presence of $\beta-\mathrm{CH}_{2}$ groups at $\mathrm{C}-2, \mathrm{C}-8, \mathrm{C}-9$ positions. While $\gamma-\mathrm{CH}_{2}$ groups at $\mathrm{C}-4, \mathrm{C}-6, \mathrm{C}-10$ positions $(\mathrm{J}=2.65)$ showed doublet at $\delta 1.61$ and the presence of $\gamma-\mathrm{CH}$ groups at $\mathrm{C}-3, \mathrm{C}-5, \mathrm{C}-7$ showed singlet at $\delta 1.2$. Chromium complex showed and confirmed the complex formation signal at $\delta 1.65$ confirmed the presence of $\beta-\mathrm{CH}_{2}$ groups for $\mathrm{C}-2, \mathrm{C}-8, \mathrm{C}-9$ positions. The $\gamma-\mathrm{CH}_{2}$ groups at $\mathrm{C}-4, \mathrm{C}-6$, $\mathrm{C}-10$ positions and $\gamma-\mathrm{CH}$ groups at $\mathrm{C}-3, \mathrm{C}-5, \mathrm{C}-7$ showed singlet at $\delta 1.6$ and $\delta 1.43$. Manganese complex showed signals at $\delta 1.65$ having coupling constant $\mathrm{J}=2.65$ confirmed the presence of $\beta-\mathrm{CH}_{2}$ groups for $\mathrm{C}-2, \mathrm{C}-8, \mathrm{C}-9$ positions. $\gamma-\mathrm{CH}_{2}$ groups at $\mathrm{C}-4, \mathrm{C}-6, \mathrm{C}-10$ positions and $\gamma-\mathrm{CH}$ groups at $\mathrm{C}-3, \mathrm{C}-5, \mathrm{C}-7$ showed singlet at $\delta 1.9$ and 1.32 . 


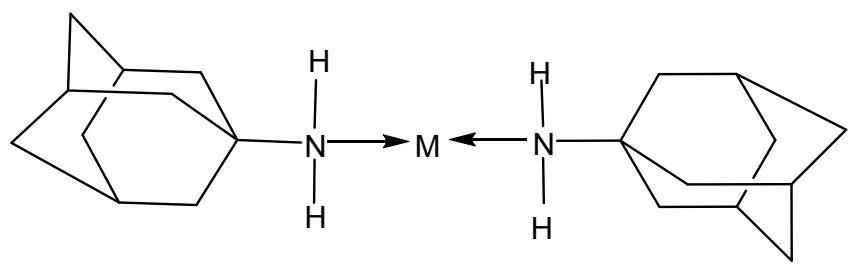

Figure 2: Proposed structure of amantadine metal complexes.

\begin{tabular}{|c|c|c|c|c|c|c|c|c|}
\hline S.No & Compound & Chemical formula & & C & H & $\mathbf{N}$ & $\mathrm{Cl} / \mathrm{S}$ & Metal \\
\hline \multirow[t]{2}{*}{1} & Amantadine & $\mathrm{C}_{10} \mathrm{H}_{17} \mathrm{~N}$ & Found & 79.41 & 11.33 & 9.26 & & \\
\hline & & & Calculated & 79.75 & 11.9 & 8.79 & & \\
\hline \multirow[t]{2}{*}{2} & $\mathrm{Amn}+\mathrm{Mg}$ & $\mathrm{C}_{10} \mathrm{H}_{17} \mathrm{Cl}_{2} \mathrm{Mg}_{2} \mathrm{NO}$ & Found & 41.88 & 5.98 & 4.88 & & 16.50 \\
\hline & & & Calculated & 40.91 & 4.78 & 5.46 & 24.73 & 16.02 \\
\hline \multirow[t]{2}{*}{3} & $\mathrm{Amn}+\mathrm{Ca}$ & $\mathrm{C}_{10} \mathrm{H}_{15} \mathrm{Cl}_{2} \mathrm{Ca}_{2} \mathrm{~N}$ & Found & 40.0 & 5.03 & 4.66 & & 26.69 \\
\hline & & & Calculated & 40.45 & 5.1 & 3.79 & 23.61 & 26.59 \\
\hline \multirow[t]{2}{*}{4} & $\mathrm{Amn}+\mathrm{Cr}$ & $\mathrm{C}_{20} \mathrm{H}_{32} \mathrm{Cl}_{2} \mathrm{CrN}_{2}$ & Found & 56.47 & 8.06 & 6.59 & 16.67 & 12.22 \\
\hline & & & Calculated & 56.42 & 8.10 & 6.53 & 16.63 & 12.20 \\
\hline \multirow[t]{2}{*}{5} & $A m n+M n$ & $\mathrm{C}_{20} \mathrm{H}_{32} \mathrm{Cl}_{2} \mathrm{MnN}_{2}$ & Found & 56.08 & 8.00 & 6.54 & 16.55 & 12.83 \\
\hline & & & Calculated & 56.05 & 8.01 & 6.58 & 16.50 & 12.88 \\
\hline \multirow[t]{2}{*}{6} & Amn + Fechloride & $\mathrm{C}_{20} \mathrm{H}_{32} \mathrm{ClFeN}_{2}$ & Found & 55.96 & 7.98 & 6.53 & 16.52 & 13.01 \\
\hline & & & Calculated & 55.91 & 7.93 & 6.58 & 16.57 & 13.09 \\
\hline \multirow[t]{2}{*}{7} & Amn + Fe sulfate & $\mathrm{C}_{20} \mathrm{H}_{32} \mathrm{FeN}_{2} \mathrm{O}_{4} \mathrm{~S}$ & Found & 53.10 & 7.13 & 6.19 & & 12.34 \\
\hline & & & Calculated & 52.51 & 7.55 & 5.54 & 7.09 & 11.93 \\
\hline \multirow[t]{2}{*}{8} & $\mathrm{Amn}+\mathrm{Co}$ & $\mathrm{C}_{20} \mathrm{H}_{32} \mathrm{ClCoN}_{2}$ & Found & 55.56 & 7.93 & 6.48 & 16.40 & 13.63 \\
\hline & & & Calculated & 55.59 & 7.99 & 6.42 & 16.47 & 13.68 \\
\hline \multirow[t]{2}{*}{9} & $\mathrm{Amn}+\mathrm{Ni}$ & $\mathrm{C}_{20} \mathrm{H}_{32} \mathrm{CIN}{ }_{2} \mathrm{Ni}$ & Found & 55.59 & 7.93 & 6.48 & 16.41 & 13.58 \\
\hline & & & Calculated & 55.61 & 7.99 & 6.50 & 16.47 & 13.60 \\
\hline \multirow[t]{2}{*}{10} & $A m n+Z n$ & $\mathrm{C}_{20} \mathrm{H}_{32} \mathrm{ClN}_{2} \mathrm{Zn}$ & Found & 54.75 & 7.81 & 6.38 & 16.16 & 14.90 \\
\hline & & & Calculated & 54.70 & 7.88 & 6.42 & 16.20 & 14.96 \\
\hline \multirow[t]{2}{*}{11} & $\mathrm{Amn}+\mathrm{Cd}$ & $\mathrm{C}_{20} \mathrm{H}_{32} \mathrm{CdClN}_{2}$ & Found & 49.45 & 7.05 & 5.77 & 14.60 & 23.14 \\
\hline & & & Calculated & 49.50 & 7.10 & 5.81 & 14.66 & 23.17 \\
\hline
\end{tabular}

Table 5: CHN microanalysis of amantadine and its metal complexes.

Ferrous sulfate complex showed a doublet at $\delta 1.68$ having coupling constant $\mathrm{J}=11.59$ confirmed the presence of $\beta-\mathrm{CH}_{2}$ groups for $\mathrm{C}-2$, $\mathrm{C}-8, \mathrm{C}-9$ positions. $\delta-\mathrm{CH}_{2}$ groups at $\mathrm{C}-4, \mathrm{C}-6, \mathrm{C}-10$ positions and $\gamma-$ $\mathrm{CH}$ groups at $\mathrm{C}-3, \mathrm{C}-5, \mathrm{C}-7$ showed singlet at $\delta 1.82$ and $\delta 2.7$. Similarly in ferric chloride complex doublet was observed at $\delta 1.68(\mathrm{~J}=11.6)$ and at $\delta 1.49$ indicated the $\mathrm{NH}_{2}$ group for $\mathrm{C}-1$, confirmed the complex formation, and $\beta-\mathrm{CH}_{2}$ groups for $\mathrm{C}-2, \mathrm{C}-8, \mathrm{C}-9$ positions.

The $\gamma-\mathrm{CH}_{2}$ groups $(\mathrm{C}-4, \mathrm{C}-6, \mathrm{C}-10)$ and $\gamma-\mathrm{CH}$ groups (C-3, $\mathrm{C}-5$, $\mathrm{C}-7)$ appeared at $\delta 1.96$ (singlet) and at $\delta 1.29$ (singlet). In the cobalt complex, the ${ }^{1} \mathrm{NMR}$ in $\mathrm{CD}_{3} \mathrm{OD}$ at $600 \mathrm{MHz}$, confirmed the complex formation by showing doublet at $\delta 1.35$ having coupling constant $\mathrm{J}=2.71$ confirmed the presence of $\beta-\mathrm{CH}_{2}$ groups for $\mathrm{C}-2, \mathrm{C}-8, \mathrm{C}-9$ positions. At $\delta 1.8(\mathrm{~d}, 6 \mathrm{H}, \mathrm{J}=1.84, \mathrm{H}-4,6,10)$ and singlet at $\delta 1.61(\mathrm{C}-3$, $\mathrm{C}-5, \mathrm{C}-7)$ showed the presence of $\delta-\mathrm{CH}_{2}$ groups and $\gamma-\mathrm{CH}$ groups. For nickel complex, a doublet at $\delta 1.6$ having coupling constant $\mathrm{J}=2.7$ confirmed the presence of $\beta-\mathrm{CH}_{2}$ groups for $\mathrm{C}-2, \mathrm{C}-8, \mathrm{C}-9$ positions. A singlet appeared at $\delta 1.98$ assigned for $\delta-\mathrm{CH}_{2}$ groups (C-4, C-6, and $\mathrm{C}-10)$ and $\gamma-\mathrm{CH}$ groups $(\mathrm{C}-3, \mathrm{C}-5$, and $\mathrm{C}-7)$ showed singlet at $\delta 1.63$ confirmed by signals $\delta 1.78(\mathrm{~d}, 2 \mathrm{H}, \mathrm{J}=12.5)$ for $\beta-\mathrm{CH}_{2}$ groups at $\mathrm{C}-2$, $\mathrm{C}-8, \mathrm{C}-9$ positions. While $\delta-\mathrm{CH}_{2}$ groups at $\mathrm{C}-4, \mathrm{C}-6, \mathrm{C}-10$ positions and $\mathrm{CH}$ groups at $\mathrm{C}-3, \mathrm{C}-5, \mathrm{C}-7$ showed singlet at $\delta 1.65$ and at $\delta 1.9$. In zinc complex, a doublet at $\delta 1.69$ having coupling constant $\mathrm{J}=11.71$ confirmed the presence of $\beta-\mathrm{CH}_{2}$ groups for $\mathrm{C}-2, \mathrm{C}-8, \mathrm{C}-9$ positions. A doublet appeared at $\delta 1.83(\mathrm{~J}=2.1)$ for $\delta-\mathrm{CH}_{2}$ groups at $\mathrm{C}-4, \mathrm{C}-6$, $\mathrm{C}-10$ positions and singlet for $\mathrm{CH}$ groups $(\mathrm{C}-3, \mathrm{C}-5, \mathrm{C}-7)$ at $\delta 1.66$. Similarly in cadmium complex, the complex confirmed by the signals of $\beta-\mathrm{CH}_{2}$ groups $(\mathrm{C}-2, \mathrm{C}-8, \mathrm{C}-9)$, a doublet appeared at $\delta 1.89(\mathrm{~J}=7.7)$ for $\delta-\mathrm{CH}_{2}$ groups for $\mathrm{C}-4, \mathrm{C}-6, \mathrm{C}-10$ positions and for $\gamma-\mathrm{CH}$ groups $(\mathrm{C}-3, \mathrm{C}-5, \mathrm{C}-7)$ singlet at $\delta 1.27$.

In case of all complexes the shifting of protons was observed at C2, C3 and C10 (Table 4). All the complexes showed resonance of methylene protons and other spectroscopic studies also account that there is an attachment of metal with the nitrogen of amine in amantadine molecule.

\section{Structure of amantadine metal complexes}

On the basis of above studies the amantadine nitrogen binds with metals and their proposed structures are shown as Figure 2. From the results obtained, it is proposed that amantadine forms complexes in the ratio of 2: 1 (drug: metal) [18]. The crystals of the complexes were very thin and we did not cope to obtain their X-ray crystallographs. The proposed formulae is established on the basis of spectroscopic and elemental analysis (Table 5) [6].

\section{Conclusion}

Complexes of metals of biological interest were synthesized with amantadine. The results from the elemental analysis, conductometric titration, AA spectroscopy, proton nuclear magnetic resonance and infrared studies reveals that in all complexes, amantadine acted as a monodentate ligand, two molecules of which were bound to the metal through the amino nitrogen showing a square planar geometry. 
Citation: Sultana N, Arayne MS, Haider A, Shahnaz H (2014) Synthesis and Characterization of 3s,5s,7s-Adamantan-1-Amine Complexes with Metals of Biological Interest. Mod Chem appl 2: 120. doi:10.4172/2329-6798.1000120

\section{References}

1. Davies W, Grunert RR, Haff RF, Mcgahen JW, Neumayer EM, et al. (1964) Antiviral Activity Of 1-Adamantanamine (Amantadine). Science 144: 862-863.

2. Whitley RJ, Alford CA (1978) Developmental aspects of selected antiviral chemotherapeutic agents. Annu Rev Microbiol 32: 285-300.

3. Tilley JW, Kramer MJ (1981) Aminoadamantane derivatives. Prog Med Chem 18: 1-44.

4. Fort RC (1976) Adamantane: The Chemistry of Diamond Molecules. Studies in Organic Chemistry, Volume 5, Marcel Dekker, New York, USA.

5. Fort RC, Schleyer PVR (1964)Adamantane: Consequences of the Diamondoid Structure. Chem Rev 64: 277-300.

6. Mustafa AA, Abdel-Fattah SA, Toubar SS, Sultan MA (2004) Spectrophotometric determination of acyclovir and amantadine Hydrochloride through metals complexation. Journal of Analytical Chemistry 59: 33-38.

7. Zák F, Turánek J, Kroutil A, Sova P, Mistr A, et al. (2004) Platinum(IV) complex with adamantylamine as nonleaving amine group: synthesis, characterization, and in vitro antitumor activity against a panel of cisplatin-resistant cancer cell lines. J Med Chem 47:761-763.

8. Liu SX, Wang CL, MiaoYU, Li YX, Wang EB (2005) Synthesis and Antiinfluenza Virus Activity of Polyoxometalates Containing Amantadine. Acta Chim Sinica 63: 1069-1074.
9. Liu SX, Wang CM, Zhai HJ, Li DH, Wang EB (2004) Synthesis and crystal structures of novel Keggin and Dawson polyoxometalates containing amantadine. Chinese Chemical Letters 15: 216-219.

10. Li J, Qi Y, Wang E, Li J, Wang H, etal. (2004) Synthesis, structural characterization and biological activity of polyoxometallate-containing protonated amantadine as a cation. Journal of Coordination Chemistry 57: 715-721.

11. Sridevi N, Yusuff, Mohammed KK (2008) Synthesis, characterization and kinetic studies on complex formed between amantadine hhdrochloride and sodium molybdate at physiological pH. Indian Journal of Chemistry 47A: 836-842.

12. Porter RS (2011) The Merck Manual of Diagnosis and Therapy. 19th Edition Section 22, Clinical Pharmacology, Merck \& Co Inc, New Jersey, USA.

13. Leon S (1990) Pharm Review. John Wiley \& Sons, New York, USA

14. Gringauz A (1997) Introduction to Medicinal Chemistry: How Drugs Act and Why. Wiley-VCH, New York, USA.

15. Nakamoto K (1963) Infrared spectra of inorganic and coordination compounds J. Wiley and Sons, USA.

16. Shishkin OV, Atroschenko Yu M, Gitis SS, Alifanova EN, Shakhkeldyan IV (1998) 3- Methyl-1,5-dinitro-3-azabicyclo[3.3.1]non-7-ene Acta Cryst 54: 271273.

17. Bettahara N, Salmana SR (1996) X-ray powder diffraction data for 1-adamantanol. Powder Diffraction 11: 24-25.

18. Balode D, Valters R (1980) PSR Zinat Latv Vestis Ahad Kim Ser. 227; CA. 93 168175 e. 